\title{
Analisa Variable-Variabel Yang Mempengaruhi Produktivitas Kerja Pada Perusahaan Karpet
}

\author{
Bima Fatra Ramadhan \\ Bhayangkara Jakarta Raya University \\ Rorim Panday* \\ Bhayangkara Jakarta Raya University \\ *Email:indripan@gmail.com
}

\begin{abstract}
Abstrak
Penelitian ini bertujuan untuk mengetahui dan menganalisis variabel apa yang berpengaruh secara siknifikan pada produktifitas kerja karyawan pada PT. Hernadhi Jaya Abadi. Untuk itu variabel yang diteliti adalah variabel tingkat pendidikan, pelatihan kerja, tingkat keterampilan dan disiplin kerja. Jenis penelitian ini adalah kuantitatif. Teknik sampling yang digunakan adalah sampling jenuh yang mana jumlah keseluruhan populasi dijadi sampel. Teknik pengambilan data dengan cara menyebarkan kuesioner. Responden dari penelitian ini adalah seluruh karyawan bagian produksi. Metode analisis yang dipergunakan adalah Path Analysis. Hasil dari penelitian ini menunjukkan bahwa variabel tingkat Pendidikan dan Disiplin Kerja secara signifikan memiliki hubungan dan pengaruh positif terhadap variabel Produktifitas, serta variabel tingkat Pendidikan juga secara signifikan memiliki hubungan dan pengaruh positif terhadap variabel Disiplin Kerja. Sedangkan variabel Pelatihan Kerja dan tingkat keterampilan tidak memiliki hubungan dan pengaruh positif secara siginifikan terhadap variabel Produktifitas maupun terhadap variabel bebas lainnya.
\end{abstract}

Kata Kunci: Produktifitas Kerja, tingkat Pendidikan, Pelatihan Kerja, tingkat Keterampilan, Disiplin Kerja

\section{Latar Belakang}

Biasanya masyarakat membeli karpet yang bagus dari daerah Timur Tengah. Memang bagus kapet dari Timur Tengah, namun harganya cukup mahal. Melihat kondisi seperti itu, maka menjadi peluang bagi pebisnis Indonesia untuk masuk ke dalam bisnis karpet, dengan membangun perusahaan yang menghasilkan karpet, salah satu nya PT. Hernadhi Jaya Abadi, membuat karpet yang menyerupai karpet dari daerah Timur Tengah. PT. Hernadhi Jaya Abadi atau lebih dikenal dengan HJ Karpet, didirikan pada tahun 2005, bergerak di bidang bisnis jual beli karpet permadani dan kebutuhan rumah lainnya; terus mengalami kemajuan sampai memiliki beberapa outlet di kota-kota besar di pulau Jawa. Sampai saat ini memiliki karyawan sekitar 195 orang pada berbagai divisi. PT. Hernadhi Jaya Abadi adalah salah satu dari 3 pabrik karpet handmade dengan kapasitas produksi terbesar di Indonesia.

Perusahaan ini menggunakan tenaga kerja dari anak bangsa Indonesia sendiri. Untuk dapat membuat karpet yang berkualitas sama dengan dari karpet dari daerah Timur Tengah, diperlukan sumber daya manusia atau tenaga ahli dalam membuat karpet yang nyaris sama dengan tenaga ahli yang dari Timur Tengah. Untuk itu dilakukanlah pelatihan bagi karyawan bagaimana membuat karpet yang berkualitas. 
Pada tahun 2018, perusahaan ini mampu mematok target produksinya. Namun pada pelaksanaan proses produksi, terjadi penyimpangan target produksi seperti terlihat pada tabel1.

Tabel 1 Produktivitas Kerja Karyawan Pada Tahun 2018

\begin{tabular}{ccccc}
\hline Bulan & $\begin{array}{c}\text { Jumlah Karyawan } \\
\text { Bagian Produksi }\end{array}$ & $\begin{array}{c}\text { Produksi Per } \\
\text { Bulan (meter) }\end{array}$ & $\begin{array}{c}\text { Target Produksi } \\
\text { Per Bulan (meter) }\end{array}$ & $\begin{array}{c}\text { Total } \\
\text { Produktivitas } \\
\text { (meter/orang) }\end{array}$ \\
\hline Januari & 80 & $2750 \mathrm{~m}$ & $3000 \mathrm{~m}$ & 34,37 \\
Februari & 80 & $2900 \mathrm{~m}$ & $3000 \mathrm{~m}$ & 36,25 \\
Maret & 80 & $2700 \mathrm{~m}$ & $3000 \mathrm{~m}$ & 33,75 \\
April & 80 & $3750 \mathrm{~m}$ & $3000 \mathrm{~m}$ & 34,37 \\
Mei & 80 & $2730 \mathrm{~m}$ & $3000 \mathrm{~m}$ & 34,12 \\
Juni & 90 & $3850 \mathrm{~m}$ & $4000 \mathrm{~m}$ & 42,77 \\
Juli & 100 & $4300 \mathrm{~m}$ & $5000 \mathrm{~m}$ & 43,00 \\
Agustus & 100 & $4850 \mathrm{~m}$ & $5000 \mathrm{~m}$ & 48,50 \\
September & 100 & $4950 \mathrm{~m}$ & $5000 \mathrm{~m}$ & 49,50 \\
Oktober & 100 & $4900 \mathrm{~m}$ & $5000 \mathrm{~m}$ & 49,00 \\
November & 100 & $4950 \mathrm{~m}$ & $5000 \mathrm{~m}$ & 49,50 \\
Desember & 100 & $4750 \mathrm{~m}$ & $5000 \mathrm{~m}$ & 47,50 \\
\hline
\end{tabular}

Sumber: PT. Hernadhi Jaya Abadi, 2018

Dari data tabel-1 dapat dilihat bahwa adanya kenaikan produktivitas secara keseluruhan, walaupun ada penurunan produktivitas kerja karyawan pada beberapa bulan, dan tidak tercapainya target produksi per bulan. Hal ini dapat dilihat terjadi penurunan produktivitas yang cukup siginifikan pada bulan Maret yang mana sebelumnya pada bulan Februari produktivitas sebesar 36,25 meter per orang menjadi 33,75 meter per orang. Penurunan juga bahkan terjadi dari bulan April ke bulan Mei yang mana sebelumnya 37,37 menjadi 34,12 meter per orang. Dengan adanya hal tersebut, maka tingkat konsistensi produktivitas kerja karyawan pada bagian produksi di PT. Hernadhi Jaya Abadi merupakan suatu masalah yang harus diidentifikasi dan diteliti guna mendukung keberhasilan perusahaan tersebut.

Salah satu cara mengatasi masalah di atas dengan mengadakan pelatihan. Dengan pelatihan akan menjadi salah satu proses pengembangan sumber daya manusia yang berperan dalam peningkatan keterampilan karyawan. Semua ini dilaksanakan agar pencapaian tujuan perusahaan menjadi efisien. Pelatihan dilakukan untuk karyawan baru maupun yang telah lama bekerja. Namun demikian, pelatihan saja tidak cukup, perlu juga tenaga kerja yang terampil dalam merajut karpet dan yang bersiplin dalam bekerja.

Perusahaan mengadakan pelatihan kerja kepada karyawan di bagian produksi. Pelatihan yang dilakukan adalah bagaimana cara merajut benang dalam pembuatan karpet dan sejenisnya sehingga terampil, begitu juga dalam hal menggunakan berbagai alat untuk mendukung kegiatan produksi dalam hal kecepatan pengoperasian. Pelatihan dilaksanakan dalam waktu sekitar satu bulan, namun untuk pelatihan merajut diperlukan waktu sekitar tiga bulan. Dengan adanya serangkaian pelatihan yang dilakukan, maka diharapkan akan berdampak terhadap produktivitas kerja karyawan. Jika dengan adanya pelatihan kerja masih belum bisa menghasilkan produksi yang efektif maka perusahaan perlu mempersiapkan juga memperbaiki tahapan-tahapan pelatihan yang lebih matang dan memperhatikan unsur-unsur penting dalam pelaksanaan pelatihan kerja karyawan.

Usaha lain yang dilakukan untuk pengembangan sumber daya manusia adalah untuk meningkatkan kemampuan karyawan dengan pendidikan yang dimiliki karyawan. Untuk 
meningkatkan produktivitas diperlukan program pendidikan, yang bertujuan sebagai upaya mengembangkan sumber daya manusia dalam hal kemampuan intelektual, kepribadian manusia, serta mampu menghadapi persoalan-persoalan yang dihadapi yang berkaitan dengan profesinya. Dengan tingkat pendidikan yang tinggi diharapkan dapat menghasilkan sumber daya manusia yang berkualitas dan mampu memberikan kontribusi terbaik, yaitu meningkatkan produktivitas dalam pencapaian tujuan perusahaan.

Selain itu juga, disiplin kerja merupakan faktor yang erat kaitannya dengan produktivitas. Perusahaan yang memiliki tenaga kerja yang disiplin cenderung memiliki tingat produktivitas yang tinggi. Sehingga penting bagi PT. Hernadhi Jaya Abadi untuk memperhatikan kedisiplinan kerja karyawan khususnya bagian produksi. Sebagai contoh kurangnya kedisiplinan dalam bekerja, adalah membiarkan alat produksi yang sudah selesai diletakkan bukan pada tempat yang seharusnya. Berdasarkan uraian latar belakang yang disampaikan di atas, maka yang menjadi rumusan masalah dalam penelitian ini adalah :

1. Bagaimana pengaruh tingkat pendidikan kerja terhadap produktifitas kerja karyawan?

2. Bagaimana pengaruh pelatihan kerja terhadap produktifitas kerja karyawan?

3. Bagaimana pengaruh keterampilan terhadap produktifitas kerja karyawan?

4. Bagaimana pengaruh disiplin kerja terhadap produktivitas kerja karyawan?

5. Bagaimana pengaruh tingkat pendidikan terhadap pelatihan kerja karyawan?

6. Bagaimana pengaruh pelatihan kerja terhadap tingkat keterampilan kerja karyawan?

7. Bagaimana pengaruh tingkat keterampilan kerja terhadap disiplin kerja karyawan?

8. Bagaimana pengaruh tingkat pendidikan terhadap tingkat keterampilan kerja karyawan?

9. Bagaimana pengaruh tingkat pendidikan terhadap disiplin kerja karyawan?

\section{Landasan Teori dan Pengembangan Hipotesis}

\section{Pengertian Produktifitas}

Produktivitas kerja hal yang sangat penting bagi perusahaan, karena dengan produktivitas dapat menentukan tingkat pencapaian. Keuntungan dan kerugian tergantung pada sebagian besar produktivitas tenaga kerja dalam suatu perusahaan, yaitu seberapa besar produktif karyawan dalam bekerja. (Tri Wijayati Wardoyo, 2015).Setiap perusahaan yang menghasilkan suatu produk atau jasa perlu memperhatikan terkait hal-hal yang dapat meningkatkan produktivitasnya. Produktivitas adalah seni untuk mendapatkan produk dan atau layanan perusahaan kepada pelanggan dengan biaya dan waktu seefisien mungkin. Produktivitas juga terkait dengan kualitas, dengan kebutuhan pelanggan dan hubungan industri. Lebih jauh lagi berarti bahwa produktivitas dan manajemen yang baik saling terkait. (Kelepile, 2015)

Untuk tercapainya produktivitas yang tinggi membutuhkan penghapusan pemborosan dalam segala bentuk, seperti pemborosan waktu, tenaga manusia, ruang, material, mesin, dan sumber daya. Produktivitas yang tinggi mengarah pada pertumbuhan ekonomi dan meningkatkan profitabilitas dan kemajuan sosial. (Sharma, Professor, \& Sharma Assistant Professor, 2014)

Produktivitas juga biasanya didefinisikan sebagai rasio input terhadap output. (Oloke, Oni, Babalola, \& Ojelabi, 2017). Hal yang mendasar untuk untuk mencapai produktivitas ekonomi suatu organisasi atau perusahaan adalah dengan kekuatan dan kualitas sumber daya manusia. Sumber daya manusia mengacu pada keterampilan, kemampuan, kompetensi, dan kualitas karyawan dalam bekerja. (Maduka \& Okafor, 2014)

Produktivitas tenaga kerja berkaitan dengan jumlah output yang diperoleh dari setiap karyawan. Ini adalah ukuran utama efisiensi bisnis, terutama untuk perusahaan di mana proses produksinya adalah dari apa yang dihasilkan tenaga kerja. (Sharma et al., 2014). 
Produktivitas adalah perbandingan antara hasil yang dicapai dengan keseluruhan daya atau faktor produksi yang digunakan. Sedangkan produktivitas tenaga kerja adalah perbandingan antara hasil yang dicapai dengan peran serta tenaga kerja persatuan waktu, atau sejumlah barang atau jasa yang dapat dihasilkan oleh seseorang atau kelompok orang/karyawan dalam jangka waktu tertentu. (Ardana, 2012)

\section{Faktor-Faktor Yang Mempengaruhi Produktifitas}

Menurut (Sharma et al., 2014) faktor-faktor yang memberikan pengaruh besar pada tingkat produktivitas dapat diklasifikasikan ke dalam dua kategori besar, yaitu: Faktor Internal: Faktor Teknologi, Faktor Keuangan, Bahan dan Energi, Faktor Manusia dan Faktor Eksternal: Faktor Alam, Faktor Sosial, Kebijakan Pemerintah, manajerial.

Sedangkan menurut (Ardana, 2012) produktifitas tenaga kerja termasuk pengukuran produktivitas parsial, sehingga ada beberapa faktor yang mempengaruhi produktivitas karyawan, antara lain: Pendidikan, Keterampilan, dan Disiplin.

Menurut (Sharma et al., 2014) produktifitas bervariasi dengan jumlah produksi dan jumlah sumber daya yang digunakan. Menurut (Sharma et al., 2014) ada beberapa hal yang menyebabkan produktifitas menjadi buruk, diantaranya kurangnya tenaga kerja terampil.

\section{Tingkat Pendidikan}

Menurut (Tirtarahardja, 2012) menjelaskan pendidikan memiliki pengertian pada batasannya masing-masing, salah satunya adanya pendidikan sebagai penyiapan tenaga kerja. Menurut (Pribadi, 2013) yang dimaksud dengan pendidikan adalah suatu pembinaan dalam proses pengembangan manusia, dimana manusia itu belajar untuk berpikir sendiri dan mendorong berkembangnya kemampuan- kemampuan dasar yang ada padanya. Dalam (Pakpahan, Siswidiyanto, \& Sukanto, 2014) Menurut UU SISDIKNAS No. 20 Tahun 2003, indikator pendidikan adalah berdasarkan tingkat/jenjang pendidikan (pendidikan formal) dan pendidikan nonformal.

\section{Pelatihan, keterampilan dan disiplin}

Pelatihan adalah kegiatan penting untuk pengelolaan sumber daya manusia di organisasi mana pun, pelatihan dapat didefinisikan sebagai proses perubahan perilaku, pengetahuan dan motivasi karyawan dapat dicapai untuk meningkatkan kompatibilitas antara karakteristik dan kemampuan karyawan dan persyaratan pekerjaan (Diab, 2015). Pelatihan adalah proses sistematis untuk meningkatkan keterampilan, pengetahuan, dan kompetensi karyawan, yang diperlukan untuk melakukan pekerjaan secara efektif. (Saeed et al., 2013).

Pelatihan adalah modifikasi perilaku yang sistematis melalui pembelajaran yang terjadi sebagai hasil dari pengajaran, pendidikan, pengembangan dan pengalaman yang direncanakan, agar menjadi terampil. (Bakan, 2010).

Menurut (Maringan, Pongtuluran, \& Maria, 2016) keterampilan adalah kecakapan atau keahlian untuk melakukan suatu pekerjaan hanya diperoleh dalam praktek. Sedangkan menurut (Melati, Minarsih, \& Fathoni, 2016) keterampilan adalah suatu kemampuan untuk menerjemahkan pengetahuan kedalam praktis sehingga tercapai tujuan yang diinginkan. Menurut (Notoatmodjo, 2015) keterampilan merupakan aplikasi dari pengetahuan sehingga tingkat keterampilan seseorang berkaitan dengan tingkat pengetahuan, dan sedangkan pengetahuan yang dipengaruhi oleh : tingkat pendidikan, umur, dan pengalaman

Menurut (Jeffrey \& Ruliyanto, 2017) (Tri Wijayati Wardoyo, 2015) (Idris, 2018)(Aprilynn, Simatupang, \& Saroyeni, 2018) mendefinisikan bahwa disiplin kerja adalah tingkat kepatuhan individu untuk melakukan semua pekerjaan mereka dengan benar, sesuai dengan standar yang diharapkan dengan kesadaran penuh, bukan dengan paksaan. 
INOBIS: Jurnal Inovasi Bisnis dan Manajemen Indonesia

Volume 03, Nomor 01, Desember 2019

Bima Fatra Ramadhan, Rorim Panday

Berikut adalah penelitian-penelitian terdahulu yang mendasari penelitian ini :

Tabel 2 Penelitian Terdahulu

1. (Abomeh \& Peace, 2015) dengan judul penelitiannya: Effects of Training on Employees' Productivity in Nigeria Insurance Industry, dimana pelatihan memiliki hubungan dengan produktivitas karyawan

2. (Rehman \& Mughal, 2013) dengan judul penelitiannya: Impact of technical education on the labor productivity, Pada penelitian ini menunjukkan bahwa tenaga kerja terampil meningkatkan produktivitas dan pendidikan membantu untuk mengatasi masalah produktivitas.

3. (Gambin, Green, \& Hogarth, 2012) melakukan penelitian tentang : Exploring the Links Between Skills and Productivity: Final Report, hasil utamanya terlihat pengaruh keterampilan, inovasi, dan perusahaan terhadap produktivitas

4. (Tri Wijayati Wardoyo, 2015), dengan judul penelitian: The Influence of the Discipline and Compensation against Work Productivity (Study on the Security Services Company, PT Garuda Milky Artha Surabaya),pada hasil penelitian ini terdapat pengaruh yang signifikan nilai disiplin dan kompensasi terhadap produktivitas kerja

5. (Kueng, 2017) dengan judul Penelitian: Pengaruh Tingkat Pendidikan Dan Kreativitas Terhadap Tenaga Kerja Kontrak di Sekretariat Kabupaten Mahakam Ulu. Hasil dari penelitian ini berupa temuan adanya hubungan yang positif antara variabel tingkat pendidikan dan kreativitas dengan variabel produktivitas

Berdasarkan penelitian terdahulu di atas, maka yang menjadi pembeda dan hal yang baru dalam penelitian ini adalah jumlah variabel yang lebih banyak yaitu dengan menggunakan 5 variabel yang terdiri dari 4 variabel bebas (pendidikan, pelatihan, keterampilam dan disiplin kerja) dan 1 variabel terikat (Produktivitas kerja) dan dalam penelitian ini juga akan dianalisis bagaimana hubungan keterkaitan setiap variabelnya dengan menggunakan metode analisis jalur (path analysis). 
Hubungan variabel tersebut dinyatakan dalam gambar sebagai berikut:

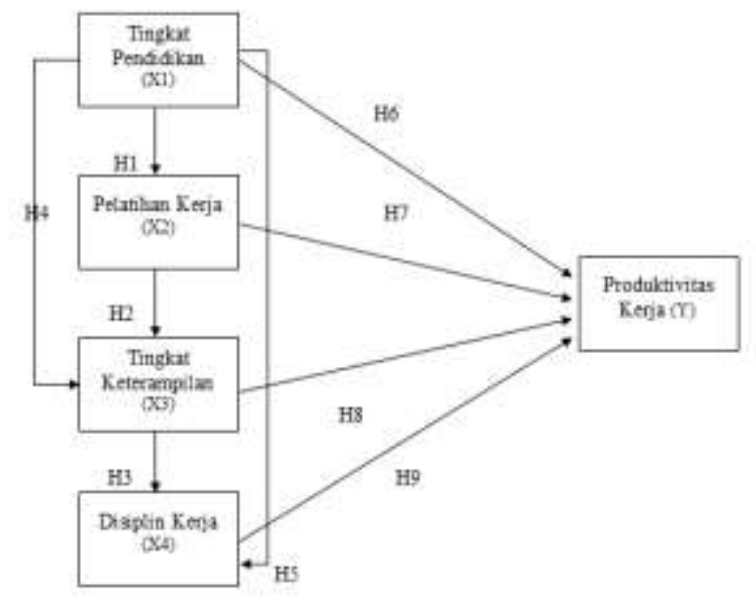

Gambar 1 Kerangka Pemikiran

Berikut merupakan hipotesis dalam penelitian ini:

1. Hipotesis 1: Terdapat pengaruh tingkat pendidikan kerja terhadap produktifitas kerja karyawan?

2. Hipotesis 2: Terdapat pengaruh pelatihan kerja terhadap produktifitas kerja karyawan?

3. Hipotesis 3: Terdapat pengaruh keterampilan terhadap produktifitas kerja karyawan?

4. Hipotesis 4: Terdapat pengaruh disiplin kerja terhadap produktivitas kerja karyawan?

5. Hipotesis 5: Terdapat pengaruh tingkat pendidikan terhadap pelatihan kerja karyawan?

6. Hipotesis 6: Terdapat pengaruh pelatihan kerja terhadap tingkat keterampilan kerja karyawan?

7. Hipotesis 7: Terdapat pengaruh tingkat keterampilan kerja terhadap disiplin kerja karyawan?

8. Hipotesis 8: Terdapat pengaruh tingkat pendidikan terhadap tingkat keterampilan kerja karyawan?

9. Hipotesis 9: Terdapat pengaruh tingkat pendidikan terhadap disiplin kerja karyawan?

\section{Metode Penelitian}

Penelitian ini adalah penelitian kuantitatif, menggunakan data primer dari kuesioner dengan skala likert. Pengujian kuesioner menggunakan uji validitas dan uji reliabilitas untuk memastikan data yang digunakan valid dan reliabel. Data diolah menggunakan program SPSS dan AMOS. Tempat penelitian ini dilakukan di PT. Hernadhi Jaya Abadi yang beralamat di Jalan Raya Pengarengan No. 78 RT 04 RW 28, Bekasi Utara, Kota Bekasi. Dan waktu penelitian akan dilakukan selama 3 sampai 4 bulan yaitu pada bulan April sampai dengan Juli 2019. Sampel dalam penelitian ini adalah seluruh karyawan bagian produksi PT. Hernadhi Jaya Abadi dengan jumlah 107 orang karyawan. 
INOBIS: Jurnal Inovasi Bisnis dan Manajemen Indonesia

Volume 03, Nomor 01, Desember 2019

Bima Fatra Ramadhan, Rorim Panday

Tabel 3 Operasional Variabel

\begin{tabular}{|c|c|c|c|c|}
\hline No. & Variabel & Definisi & Indikator & $\begin{array}{c}\text { Skala } \\
\text { Pengukuran }\end{array}$ \\
\hline 1. & $\begin{array}{l}\text { Produktivtas } \\
\text { Kerja }\end{array}$ & $\begin{array}{l}\text { Suatu kemampuan } \\
\text { seseorang / organisasi / } \\
\text { perusahaan dalam } \\
\text { menghasilkan barang } \\
\text { atau jasa dalam jangka } \\
\text { waktu tertentu dengan } \\
\text { memanfaatkan sumber } \\
\text { daya yang ada dengan } \\
\text { cara-cara efektif dan } \\
\text { efisien. }\end{array}$ & $\begin{array}{ll}\text { a. Kemampuan } \\
\text { b. } & \begin{array}{l}\text { Berusaha } \\
\text { meningkatkan } \\
\text { hasil yang }\end{array} \\
\text { dicapai } \\
\text { c. Semangat } \\
\text { Kerja } \\
\text { d. Efisiensi } \\
\text { (Sutrisno, } \\
\text { 2009) }\end{array}$ & Likert \\
\hline 2. & $\begin{array}{l}\text { Tingkat } \\
\text { Pendidikan }\end{array}$ & $\begin{array}{l}\text { Suatu proses yang } \\
\text { penting bagi seseorang } \\
\text { untuk mengembangkan } \\
\text { dirinya dengan cara } \\
\text { belajar sehingga } \\
\text { memiliki kemampuan- } \\
\text { kemampuan mendasar } \\
\text { hingga yang khusus. }\end{array}$ & $\begin{array}{ll}\text { a. } & \text { Pendidikan } \\
\text { Dasar } \\
\text { b. Pendidikan } \\
\text { Atas } \\
\text { c. Pendidikan } \\
\text { Tinggi } \\
\text { UU } \\
\text { SISDIKNAS } \\
\text { No. 20 Tahun } \\
\text { 2003 dalam } \\
\text { (Pakpahan et } \\
\text { al., 2014) }\end{array}$ & Likert \\
\hline 3. & $\begin{array}{l}\text { Pelatihan } \\
\text { Kerja }\end{array}$ & $\begin{array}{l}\text { Suatu proses yang } \\
\text { terencana untuk } \\
\text { mempersiapkan } \\
\text { seseorang agar siap } \\
\text { bekerja dengan cara } \\
\text { meningkatkan } \\
\text { kemampuan, } \\
\text { pengetahuan dan } \\
\text { keterampilannya yang } \\
\text { juga tujuannya sebagai } \\
\text { pengembangan sumber } \\
\text { daya manusia. }\end{array}$ & $\begin{array}{ll}\text { a. Jenis } \\
\text { Pelatihan } \\
\text { b. Materi } \\
\text { Pelatihan } \\
\text { c. Waktu } \\
\text { Pelatihan } \\
\text { (Pakpahan et } \\
\text { al., 2014) }\end{array}$ & Likert \\
\hline 4. & $\begin{array}{l}\text { Tingkat } \\
\text { Keterampilan }\end{array}$ & $\begin{array}{l}\text { Kemampuan seseorang } \\
\text { untuk menjalankan tugas } \\
\text { atau pekerjaannya } \\
\text { berdasarkan ilmu dan } \\
\text { pengalaman yang pernah } \\
\text { dilakukan dan itu sudah }\end{array}$ & $\begin{array}{ll}\text { a. Kecakapan } \\
\text { b. Kemampuan } \\
\text { c. Ketelitian } \\
\text { (Suwatno, } \\
\text { 2016) }\end{array}$ & Likert \\
\hline
\end{tabular}


menjadi kebiasaan yang

ada pada dirinya.

\begin{tabular}{|c|c|c|c|}
\hline 5. Disiplin Kerja & $\begin{array}{l}\text { Suatu kesadaran dan } \\
\text { kemauan karyawan } \\
\text { untuk mematuhi semua } \\
\text { aturan perusahaan dan } \\
\text { norma sosial yang } \\
\text { berlaku dalam } \\
\text { melaksanakan pekerjaan } \\
\text { dan berinteraksi dengan } \\
\text { semua pihak dalam } \\
\text { perusahaan, baik yang } \\
\text { tertulis atau tidak. }\end{array}$ & $\begin{array}{l}\text { a. Ketepatan } \\
\text { Waktu } \\
\text { b. Pemanfaatan } \\
\text { Sarana } \\
\text { c. Tanggung } \\
\text { Jawab yang } \\
\text { Tinggi } \\
\text { d. Ketaatan } \\
\text { terhadap } \\
\text { Peraturan } \\
\text { Perusahaan } \\
\text { (Jundah Ayu } \\
\text { Permatasari, } \\
\text { Mochammad AL } \\
\text { Musadieq, 2015) }\end{array}$ & Likert \\
\hline
\end{tabular}

\section{Analisis Jalur (Path Analysis)}

Analisis jalur merupakan teknik statistik yang dipakai untuk menguji hubungan kausal antara dua atau lebih variabel. Analisis jalur digunakan untuk menganalisis pola hubungan antar variabel dengan tujuan untuk mengetahui pengaruh langsung ataupun tidak langsung dari variable-variabel terkait (Neolaka, 2014). Hubungan dinyatakan ada dan berpengaruh jika nilai $\mathrm{p}<0,05$ untuk nilai CR (critical Value) dari hubungan.

\section{Pembahasan}

Karakteristik Responden Berdasarkan Jenis Kelamin

Table 4 Responden Berdasarkan Jenis Kelamin

\begin{tabular}{cccc}
\hline No & Jenis Kelamin & Jumlah & Persentase \\
\hline 1 & Laki - Laki & 52 & $49 \%$ \\
2 & Perempuan & 55 & $51 \%$ \\
\hline & Total & 107 & $100 \%$ \\
\hline
\end{tabular}

Berdasarkan table 4, diketahui bahwa jumlah responden berdasarkan jenis kelamin Laki laki sebanyak 52 responden dengan persentase $49 \%$ dan jenis kelamin perempuan sebanyak 55 responden dengan persentase 51\%. Karakteristik Responden Berdasarkan Usia 
INOBIS: Jurnal Inovasi Bisnis dan Manajemen Indonesia

Volume 03, Nomor 01, Desember 2019

Bima Fatra Ramadhan, Rorim Panday

Tabel 5 Responden Berdasarkan Usia

\begin{tabular}{cccc}
\hline No & Tingkat Usia & Jumlah & Persentasi \\
\hline 1 & $18-25$ Tahun & 38 & $38 \%$ \\
2 & $26-35$ Tahun & 42 & $43 \%$ \\
3 & $36-45$ Tahun & 18 & $18 \%$ \\
4 & $46-55$ Tahun & 9 & $1 \%$ \\
\hline & Total & 107 & $100 \%$
\end{tabular}

Table 5 dapat disimpulkan bahwa jumlah responden berdasarkan usia dalam penelitian ini yang memiliki jumlah terbanyak adalah responden usia 26 - 35 tahun yaitu sebanyak 42 dengan persentase $43 \%$, jumlah kedua terbanyak adalah yang berusia $18-25$ tahun yaitu sebanyak 38 dengan persentase $38 \%$. Jumlah ketiga terbanyak adalah berusia 36 - 45 dengan jumlah 18 dan persentase $18 \%$ sedangkan yang terkecil adalah yang berusia $46-55$ tahun dengan jumlah 9 dan persentase sebanyak $1 \%$. Karakteristik Responden Berdasarkan Tingkat Pendidikan

Tabel 6 Responden Berdasarkan Tingkat Pendidikan

\begin{tabular}{cccc}
\hline No & Tingkat Pendidikan & Jumlah & Persentase \\
\hline 1 & SD & 10 & $9 \%$ \\
2 & SMP & 17 & $16 \%$ \\
3 & SMA/K & 77 & $72 \%$ \\
4 & Sarjana & 3 & $3 \%$ \\
\hline & Total & 107 & $100 \%$ \\
\hline
\end{tabular}

Dari table 6 memperlihatkan presentase responden terbanyak adalah lulusan SMA/K dengan jumlah 77 dan persentase $72 \%$ sedangkan responden paling sedikit yaitu yang berpendidikan Sarjana yaitu sejumlah 3 dengan persentase $3 \%$.

\section{Uji Kuesioner}

Untuk uji validitas dan reliabilitas, menggunakan data keseluruhan sampel sebanyak 107 responden, dimana $\mathrm{df}=\mathrm{n}-2$ atau $107-2=105$, didapat $\mathrm{r}$ tabel $=0,1900$. Selanjutnya dibandingkan antara $r$ hitung dengan $r$ tabel sebagai berikut : 
Bima Fatra Ramadhan, Rorim Panday

Tabel 7 Hasil Uji Validitas

\begin{tabular}{cccc}
\hline \multicolumn{4}{c}{ Uji Validitas tingkat Pendidikan $(\mathrm{X} 1)$} \\
\hline Butir Pertanyaan & R hitung & R Tabel & Keterangan \\
\hline Pertanyaan 1 & 0,659 & 0.1900 & Valid \\
Pertanyaan 2 & 0,867 & 0.1900 & Valid \\
Pertanyaan 3 & 0,646 & 0.1900 & Valid \\
Pertanyaan 4 & 0,726 & 0.1900 & Valid \\
Pertanyaan 5 & 0,785 & 0.1900 & Valid \\
\hline \multicolumn{4}{c}{ Uji Validitas Pelatihan Kerja (X2) } \\
\hline Butir Pertanyaan & R hitung & R Tabel & Keterangan \\
\hline Pertanyaan 1 & 0,679 & 0.1900 & Valid \\
Pertanyaan 2 & 0,855 & 0.1900 & Valid \\
Pertanyaan 3 & 0,668 & 0.1900 & Valid \\
Pertanyaan 4 & 0,535 & 0.1900 & Valid \\
Pertanyaan 5 & 0,855 & 0.1900 & Valid
\end{tabular}

Uji Validitas Tingkat Keterampilan (X3)

\begin{tabular}{cccc}
\hline Butir Pertanyaan & R hitung & R Tabel & Keterangan \\
\hline Pertanyaan 1 & 0,571 & 0.1900 & Valid \\
Pertanyaan 2 & 0,632 & 0.1900 & Valid \\
Pertanyaan 3 & 0,695 & 0.1900 & Valid \\
Pertanyaan 4 & 0,713 & 0.1900 & Valid \\
Pertanyaan 5 & 0,668 & 0.1900 & Valid \\
\hline
\end{tabular}

\begin{tabular}{cccc}
\hline \multicolumn{4}{c}{ Uji Validitas Disiplin Kerja (X4) } \\
\hline Butir Pertanyaan & R hitung & R Tabel & Keterangan \\
\hline Pertanyaan 1 & 0,699 & 0.1900 & Valid \\
Pertanyaan 2 & 0,792 & 0.1900 & Valid \\
Pertanyaan 3 & 0,840 & 0.1900 & Valid \\
Pertanyaan 4 & 0,702 & 0.1900 & Valid \\
Pertanyaan 5 & 0,728 & 0.1900 & Valid \\
\hline Uji Validitas Produktifitas Kerja (Y) \\
\hline Butir Pertanyaan & R hitung & R Tabel & Keterangan \\
\hline Pertanyaan 1 & 0,659 & 0.1900 & Valid \\
Pertanyaan 2 & 0,515 & 0.1900 & Valid \\
Pertanyaan 3 & 0,844 & 0.1900 & Valid \\
Pertanyaan 4 & 0,768 & 0.1900 & Valid \\
\hline Pertanyaan 5 & 0,747 & 0.1900 & Valid
\end{tabular}

Dari tabel di atas dapat dilihat bahwa nilai $r$ hitung nilainya lebih besar dari $r$ tabel, sehingga dapat disimpulkan bahwa butiran pertanyaan dari setiap variabel dinyatakan valid.

Uji reliabilitas merupakan uji kehandalan yang digunakan untuk mengetahui seberapa jauh sebuah alat ukur dapat diandalkan.

Tabel 8 Hasil Uji Reliabilitas

\begin{tabular}{ccccc}
\hline $\mathrm{X} 1$ & $\mathrm{X} 2$ & $\mathrm{X} 3$ & $\mathrm{X} 4$ & $\mathrm{Y}$ \\
\hline .789 & .756 & .671 & .802 & .753 \\
\hline
\end{tabular}


Hasil Uji reabilitas Nilai Cronbach's Alpha sudah lebih besar dari 0,60, maka hasil dari kuesioner yang disebar memiliki tingkat reliabilitas yang baik.

\section{Path Analysis (Analisis Jalur)} berikut:

Adapun bentuk path diagram hasil olahan data lewat Amos didapatkan hasil sebagai

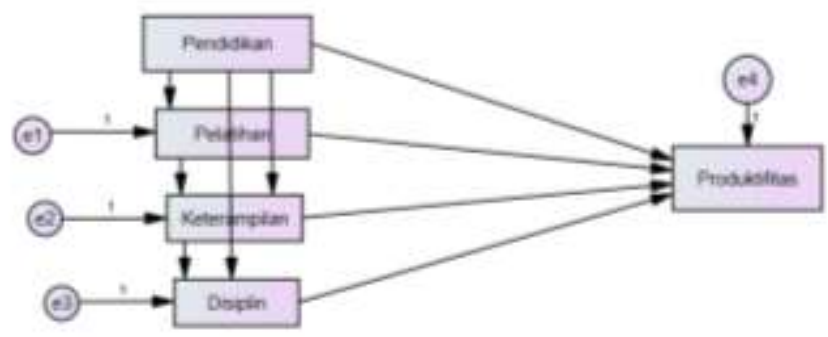

Gambar 2 Path Diagram

Berdasarkan gambar Path Diagram di atas, dapat diturunkan dalam bentuk table hubungan antar variabel seperti dibawah ini :

Tabel 9 Hubungan Antar Variabel

\begin{tabular}{|c|c|c|c|c|c|}
\hline \multicolumn{3}{|c|}{ Variabel } & Koefisien & Sig & $\begin{array}{c}\text { Sifat } \\
\text { Hubungan }\end{array}$ \\
\hline Pendidikan & $\longrightarrow$ & Pelatihan Kerja & 0,60 & 0,534 & Langsung \\
\hline Pelatihan Kerja & $\longrightarrow$ & Keterampilan & 0,59 & 0,539 & Langsung \\
\hline Pendidikan & & Keterampilan & 0,87 & 0,367 & $\begin{array}{l}\text { Tidak } \\
\text { Langsung }\end{array}$ \\
\hline Keterampilan & $\longrightarrow$ & Disiplin Kerja & 0,97 & 0,295 & Langsung \\
\hline Pendidikan & & Disiplin Kerja & 0,303 & 0,001 & $\begin{array}{l}\text { Tidak } \\
\text { Langsung }\end{array}$ \\
\hline Pendidikan & & Produktifitas & 0,250 & 0,000 & Langsung \\
\hline Pelatihan Kerja & $\longrightarrow$ & Produktifitas & $-0,024$ & 0,727 & Langsung \\
\hline Keterampilan & $\longrightarrow$ & Produktifitas & 0,070 & 0,317 & Langsung \\
\hline Disiplin Kerja & $\longrightarrow$ & Produktifitas & 0,571 & 0,000 & Langsung \\
\hline
\end{tabular}

Dari hubungan antara variabel diatas, diperoleh model terdiri dari 9 paths (jalur). 9 paths tersebut tersusun atas 7 paths hubungan langsung dan 2 paths hubungan tidak langsung. 


\section{Uji Hipotesis}

Yang dijadikan dasar pengambilan keputusan uji signifikansi atas regression weight adalah sebagai berikut :

Tabel 10 Hasil Regression Weight

\begin{tabular}{cccc}
\hline Path & $\begin{array}{c}\text { Standarized } \\
\text { Beta }\end{array}$ & p- value & Keputusan \\
\hline Pelatihan $\leftarrow$ Pendidikan & 0,077 & 0,534 & Tidak Signifikan \\
Keterampilan $\leftarrow$ Pelatihan & 0,114 & 0,539 & Tidak Signifikan \\
Keterampilan $\leftarrow$ Pendidikan & 0,090 & 0,367 & Tidak Signifikan \\
Disiplin Kerja $\leftarrow$ Keterampilan & 0.117 & 0,295 & Tidak Signifikan \\
Disiplin Kerja $\leftarrow$ Pendidikan & 0.109 & 0,001 & Signifikan \\
Produktifitas $\leftarrow$ Pendidikan & 0,090 & 0,000 & Signifikan \\
Produktifitas $\leftarrow$ Pelatihan & 0,109 & 0,727 & Tidak Signifikan \\
Produktifitas $\leftarrow$ Keterampilan & 0,092 & 0,317 & Tidak Signifikan \\
Produktifitas $\leftarrow$ Disiplin Kerja & 0,076 & 0,000 & Signifikan \\
\hline
\end{tabular}

Berdasarkan tabel 10 didapatkan 3 hubungan yang siknifikan, karena nilai $\mathrm{p}<0,05$. Yaitu:

Tabel 11 hubungan variable yang siknifikan

\begin{tabular}{cccl}
\hline Disiplin Kerja $\leftarrow$ Pendidikan & 0.109 & 0,001 & Signifikan \\
Produktifitas $\leftarrow$ Pendidikan & 0,090 & 0,000 & Signifikan \\
Produktifitas $\leftarrow$ Disiplin Kerja & 0,076 & 0,000 & Signifikan \\
\hline
\end{tabular}

\section{Uji Pengaruh Langsung dan Tidak Langsung antar Variabel}

Pada penelitian ini juga akan dijelaskan pengaruh langsung dan tidak langsung antar variabel. Berikut ini adalah hasil output Amos yang menjadi acuan dalam pembahasan kali ini

Tabel 12 Hasil Standardized Direct Effects

\begin{tabular}{lrrrr}
\hline & Pendidikan & Pelatihan & Keterampilan & Disiplin \\
\hline Pelatihan & $\mathbf{. 0 6 0}$ & .000 & .000 & .000 \\
Keterampilan & .087 & $\mathbf{. 0 5 9}$ & .000 & .000 \\
Disiplin & $\mathbf{3 0 3}$ & .000 & $\mathbf{. 0 9 8}$ & .000 \\
Produktifitas & $\mathbf{. 2 5 0}$ & $\mathbf{- . 0 2 4}$ & $\mathbf{. 0 7 0}$ & $\mathbf{. 5 7 1}$ \\
\hline
\end{tabular}

Berdasarkan tabel 12 di atas dapat dilihat pengaruh langsung Pendidikan ke variabel Pelatihan adalah sebesar 0,060. Pengaruh langsung Pelatihan Kerja dengan Keterampilan sebesar 0,059. Pengaruh langsung Keterampilan dengan Disiplin Kerja sebesar 0,098. Pengaruh langsung Pendidikan dengan Produktifitas Kerja sebesar 0,250. Pengaruh langsung Pelatihan Kerja dengan Produktifitas Kerja sebesar -0,024. Pengaruh langsung Keterampilan dengan Produktifitas Kerja sebesar 0,070. Pengaruh langsung Displin Kerja 
dengan Produktifitas Kerja sebesar 0,571.

Sehingga dapat disimpulkan bahwa pengaruh langsung terbesar variabel independen terhadap variabel dependen adalah Pendidikan $(0,250)$ dan Disiplin Kerja $(0,571)$.

Tabel 13 Standardized Indirect Effects

\begin{tabular}{lrrrr}
\hline & Pendidikan & Pelatihan & Keterampilan & Disiplin \\
\hline Pelatihan & .000 & .000 & .000 & .000 \\
Keterampilan & $\mathbf{. 0 0 4}$ & .000 & .000 & .000 \\
Disiplin & $\mathbf{. 0 0 9}$ & .006 & .000 & .000 \\
Produktifitas & .183 & .007 & .056 & .000 \\
\hline
\end{tabular}

Berdasarkan tabel 13 di atas dapat dilihat pengaruh tidak langsung Pendidikan dengan Keterampilan Kerja adalah sebesar 0,004 dan pada tabel 12 sebelumnya diketahui pengaruh langsungnya sebesar 0,087. Maka karena pengaruh tidak langsung lebih kecil dibandingkan pengaruh langsung, maka dapat dikatakan tidak terjadi peran mediasi dalam model ini, atau dengan kata lain Pelatihan Kerja bukan merupakan mediator hubungan antara Pendidikan dan Keterampilan Kerja.

Kemudian pengaruh tidak langsung Pendidikan dengan Disiplin Kerja adalah sebesar 0,009 dan pada tabel 12 sebelumnya dapat diketahui pengaruh langsungnya sebesar 0,303. Maka karena pengaruh tidak langsung lebih kecil dibandingkan pengaruh langsung, maka dapat dikatakan tidak terjadi peran mediasi dalam model ini, atau dengan kata lain Pelatihan Kerja dan Keterampilan Kerja bukan merupakan mediator hubungan antara Pendidikan dan Disiplin Kerja.

1) Tingkat Pendidikan Berpengaruh Signifikan terhadap Disiplin Kerja

Koefisien jalur variabel Pendidikan terhadap variabel Disiplin Kerja 0.303. Nilai koefisien ini menunjukkan bahwa variabel Pendidikan mampu mempengaruhi variabel Disiplin Kerja sebesar 30,3\%. Artinya variabel Pendidikan mempengaruhi meningkatnya Disiplin Kerja, semakin tinggi tingkat Pendidikan maka akan semakin baik Disiplin Kerja Karyawan.

2) Tingkat Pendidikan Berpengaruh Signifikan terhadap Produktifitas Kerja

Koefisien jalur variabel Pendidikan terhadap variabel Produktifitas Kerja 0.250. Nilai koefisien ini menunjukkan bahwa variabel Pendidikan mampu mempengaruhi variabel Produktifitas Kerja sebesar 25\%, Artinya variabel Pendidikan mempengaruhi meningkatnya Produktifitas Kerja, semakin tinggi tingkat Pendidikan maka akan semakin tinggi tingkat Produktifitas Kerja Karyawan.

3) Disiplin Kerja Berpengaruh Signifikan terhadap Produktifitas Kerja Koefisien jalur variabel Disiplin Kerja terhadap variabel Produktifitas Kerja 0.571, menunjukkan bahwa variabel Disiplin Kerja mampu mempengaruhi variabel Produktifitas Kerja sebesar 57,1\%; Artinya variabel Disiplin Kerja mempengaruhi meningkatnya Produktifitas Kerja, semakin tinggi tingkat Disiplin Kerja maka akan semakin tinggi tingkat Produktifitas Kerja Karyawan. 
Sehingga hasil akhir dari model Path nya adalah sebagai berikut :

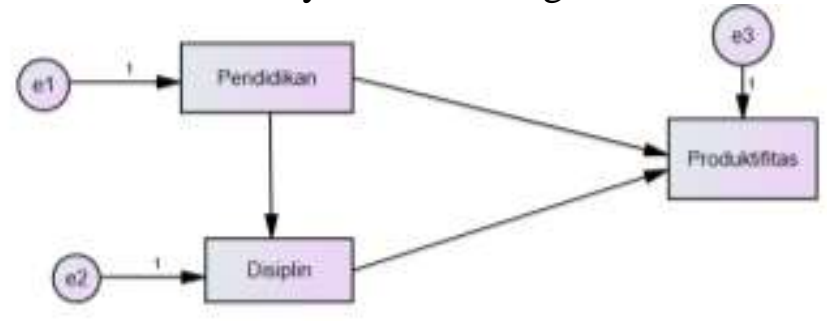

Gambar 3 Model Akhir Diagram Path

Berdasarkan pada gambar 3, maka model akhir dari path dapat disimpulkan bahwa variabel Pendidikan dan Disiplin Kerja secara signifikan memiliki hubungan dan pengaruh positif terhadap variabel Produktifitas, serta variabel Pendidikan juga secara signifikan memiliki hubungan dan pengaruh positif terhadap variabel Disiplin Kerja. Dan dengan kata lain, variabel Pendidikan memiliki hubungan dan pengaruh yang positif terhadap dua variabel yang terdiri dari 1 variabel bebas (Disiplin Kerja) dan variabel terikat (Produktifitas).

Selain itu juga dapat disimpulkan bahwa pengaruh Pendidikan melalui variabel Disiplin Kerja memiliki hubungan dan pengaruh positif yang cukup besar terhadap Produktifitas Kerja. Hal ini diketahui berdasarkan total koefisien jalur Pendidikan melalui Disiplin Kerja terhadap Produktifitas yaitu sebesar 0,303 x 0,571 =0,173, yang artinya memiliki pengaruh sebesar $17,3 \%$.

\section{Kesimpulan}

Penelitian ini bertujuan untuk mengetahui pengaruh Pendidikan, Pelatihan Kerja, tingkat Keterampilan, Disiplin Kerja terhadap Produktifitas di PT. Hernadhi Jaya Abadi baik hubungan secara langsung dan tidak langsung antar variabel. Berdasarkan hasil analisis data yang telah dilakukan, maka dapat ditarik kesimpulan bahwa Tingkat Pendidikan memiliki hubungan dan pengaruh yang positif dengan variabel Disiplin Kerja. Tingkat Pendidikan memiliki hubungan yang positif dengan variabel Produktifitas Kerja. Disiplin Kerja memiliki hubungan yang positif dengan variabel Produktifitas Kerja.

\section{Implikasi}

Hasil dari penelitian ini diharapkan memberikan dapat memberikan masuk untuk pimpinan PT. Hernadhi Jaya Abadi yang bertujuan untuk menciptakan perubahan kearah yang lebih baik. Dalam rangka mempertahankan dan meningkatkan disiplin kerja, perusahaan dapat menjadikan latar belakang pendidikan calon karyawan sebagai salah satu faktor yang mendukung tingginya kedisiplinan kerja. Selanjutnya, perusahaan harus menjadikan pendidikan sebagai salah satu faktor yang diperhatikan dalam rangka rekruitmen untuk terus meningkatkan produktifitas kerja sebagaimana yang diharapkan. Kemudian, perusahaan harus bisa mempertahankan aturan-aturan bagi karyawan yang mengatur hal-hal terkait disiplin kerja dan dapat menambah kabijakan-kebijakan positif khususnya dalam proses produksi agar tingkat produktifitas kerja semakin meningkat. 
INOBIS: Jurnal Inovasi Bisnis dan Manajemen Indonesia

Volume 03, Nomor 01, Desember 2019

Bima Fatra Ramadhan, Rorim Panday

\section{Daftar Pustaka}

Abomeh, O., \& Peace, N. (2015). Effects of Training on Employees' Productivity in Nigeria Insurance Industry. British Journal of Economics, Management \& Trade, 7(3), 227-235. https://doi.org/10.9734/bjemt/2015/15001

Aprilynn, *, Simatupang, C., \& Saroyeni, P. (2018). The Effect of Discipline, Motivation and Commitment to Employee Performance, 20(6), 31-37. https://doi.org/10.9790/487X2006013137

Ardana, K. I. (2012). Manajemen Sumber Daya Manusia (Cetakan Pe). Yogyakarta: Graha Ilmu.

Bakan, İ. S. M. A. İ. L. (2010). the Importance of Formal Employee Education in the World of Growing Uncertainty, 341-355.

Diab, S. M. (2015). The Influence of Training on Employee's Performance, Organizational Commitment, and Quality of Medical Services at Jordanian Private Hospitals. International Journal of Business and Management, 10(2), 117-127. https://doi.org/10.5539/ijbm.v10n2p117

Gambin, L., Green, A. E., \& Hogarth, T. (2012). Exploring the Links Between Skills and Productivity: Final Report, (March).

Idris, M. (2018). The Impact of Education and Training, Work Discipline and Organizational Culture on Employee's Performance: The Study of Disaster Management and Fire Department in Palembang City, Indonesia. International Journal of Human Resource Studies, 8(3), 1. https://doi.org/10.5296/ijhrs.v8i3.13013

Jeffrey, I., \& Ruliyanto. (2017). The Effect of Competence, Training and Work Discipline towards Employees ' Performance ( A Case Study at PT . Krakatau Argo Logistics ). Jurnal Internasional Penemuan Bisnis Dan Manajemen, 6(7), 77-86.

Jundah Ayu Permatasari, Mochammad AL Musadieq, Y. M. (2015). Pegaruh Disiplin Kerja dan Motivasi Kerja Terhadap Prestasi Kerja Karyawan (studi pada PT BPR Gunung Ringgir Malang). Jurnal Administrasi Bisnis, 25(1), 7-9.

Kelepile, K. (2015). Impact of Organizational Culture on Productivity and Quality Management: a Case Study in Diamond Operations Unit, DTC Botswana. International Journal of Research in Business Studies and Management International Journal of Research In, 2(9), 11.

Kueng, J. (2017). Pengaruh tingkat pendidikan dan kreativitas terhadap produktivitas tenaga kerja kontrak di sekretariat kabupaten mahakam ulu. EJournal Pemerintahan Integratif.

Maduka, C. E., \& Okafor, D. O. (2014). Effect of Motivation on Employee Productivity : A Study of Manufacturing Companies in Nnewi. International Journal of Managerial Studies and Research (IJMSR), 2(7), 137-147.

Maringan, K., Pongtuluran, Y., \& Maria, S. (2016). Pengaruh Tingkat Pendidikan, Sikap Kerja dan Keterampilan Kerja terhadap Prestasi Kerja Karyawan PT. Wahana Sumber Lestari Samarinda. Jurnal Ekonomi Dan Keuangan, 13(2), 135-150.

Melati, D. L., Minarsih, M. M., \& Fathoni, A. (2016). Pengaruh Pendidikan, Keterampilan, Basic Skill Terhadap Karir Untuk Keinginan Berpindah Kerja (Studi Empiris di Kelurahan Jatingaleh Kecamatan Candisari Kota Semarang), 2(2). 
Neolaka, A. (2014). Metode Penelitian dan Statistik. (Adriyani, Ed.) (Cetakan Pe). Bandung: PT. Remaja Rosdakarya.

Notoatmodjo, S. (2015). Pengembangan Sumber Daya Manusia. Jakarta: Rineka Cipta.

Oloke, O. C., Oni, A. S., Babalola, D. O., \& Ojelabi, R. A. (2017). Incentive Package, Employee's Productivity and Performance of Real Estate Firms in Nigeria. European Scientific Journal, 13(11), 246-260. https://doi.org/10.19044/esj.2017.v13n11p246

Pakpahan, E. S., Siswidiyanto, \& Sukanto. (2014). Pengaruh Pendidikan Dan Pelatihan Terhadap Kinerja Pegawai ( Studi pada Badan Kepegawaian Daerah Kota Malang ). Jurrnal Administrasi Publik, 2(1), 116-121. https://doi.org/10.1007/b135457

Pribadi, A. (2013). Pengaruh pendidikan dan pelatihan terhadap kemampuan dan kinerja karyawan (studi pada karyawan PDAM kota Malang). Jurnal Administrasi Bisnis, 1-10.

Rehman, A., \& Mughal, K. (2013). Impact of technical education on the labor productivity. International Journal of Economics, Finance and Management, 2(7), 462-471.

Saeed, R., Lodhi, R. N., Sarfraz, Q., Iqbal, A., Mahmood, Z., \& Ahmed, M. (2013). The effect of training on employee work. World Applied Sciences Journal, 26(3), 399-405. https://doi.org/10.5829/idosi.wasj.2013.26.03.1379

Sharma, S., Professor, A., \& Sharma Assistant Professor, V. (2014). Employee Engagement To Enhance Productivity In Current Scenario. IRACST - International Journal of Commerce, Business and Management, 3(4), 2319-2828.

Sutrisno, E. (2009). Manajemen Sumber Daya Manusia. Jakarta: Kencana.

Suwatno. (2016). Manajemen Sumber Daya Manusia. Bandung: Alfabeta.

Tirtarahardja, P. D. U. (2012). Pengantar Pendidikan (Edisi Kedu). Jakarta: PT. Rineka Cipta.

Tri Wijayati Wardoyo, D. (2015). The Influence of the Discipline and Compensation against Work Productivity (Study on the Security Services Company, PT Garuda Milky Artha Surabaya). International Journal of Business and Management, 11(1), 64. https://doi.org/10.5539/ijbm.v11n1p64 